Thomas J. Spiegel*

\title{
The Scientific Weltanschauung: (Anti-) Naturalism in Dilthey, Jaspers and Analytic Philosophy
}

\author{
https://doi.org/10.1515/itph-2021-0016
}

Published online June 23, 2021

\begin{abstract}
Different forms of methodological and ontological naturalism constitute the current near-orthodoxy in analytic philosophy. Many prominent figures have called naturalism a (scientific) image (Sellars, W. 1962. "Philosophy and the Scientific Image of Man.” In Wilfrid Sellars, Science, Perception, Reality, 1-40. Ridgeview Publishing), a Weltanschauung (Loewer, B. 2001. "From Physics to Physicalism.” In Physicalism and its Discontents, edited by C. Gillett, and B. Loewer. Cambridge: Cambridge University Press; Stoljar, D. 2010. Physicalism. Routledge), or even a "philosophical ideology" (Kim, J. 2003. "The American Origins of Philosophical Naturalism.” Journal of Philosophical Research 28: 83-98). This suggests that naturalism is indeed something over-and-above an ordinary philosophical thesis (e.g. in contrast to the justified true belief-theory of knowledge). However, these thinkers fail to tease out the host of implications this idea naturalism being a worldview - presents. This paper draws on (somewhat underappreciated) remarks of Dilthey and Jaspers on the concept of worldviews (Weltanschauung, Weltbild) in order to demonstrate that naturalism as a worldview is a presuppositional background assumption which is left untouched by arguments against naturalism as a thesis. The concluding plea is (in order to make dialectical progress) to re-organize the existing debate on naturalism in a way that treats naturalism not as a first-order philosophical claim, but rather shifts its focus on naturalism's status as a worldview.
\end{abstract}

Keywords: naturalism, worldview, ideology, Dilthey, Jaspers, scientific image

\section{Introduction}

Different versions of naturalism arguably constitute a majority view in current Anglophone, analytic philosophy. Those actively engaged in analytic philosophy

\footnotetext{
*Corresponding author: Thomas J. Spiegel, Department of Philosophy, University of Potsdam, Potsdam, Germany, E-mail: thomspiegel@uni-potsdam.de. https://orcid.org/0000-0002-79623838
}

Ә Open Access. (C 2021 Thomas J. Spiegel, published by De Gruyter. ((c))BY under the Creative Commons Attribution 4.0 International License. 
will most likely need no further convincing that this is the case. For everyone else, perhaps some evidence for this claim can be provided. For example, both Richard Rorty and Brian Leiter agree that the opposition between naturalism and Wittgensteinian quietism is the "deepest and most intractable difference of opinion within contemporary Anglophone philosophy”, their loyalty being to different sides of this fault-line (Rorty 2010, 57). Mario De Caro and David Macarthur write something similar in an influential anthology critical of naturalism: "scientific naturalism is the current orthodoxy, at least within Anglo-American philosophy" (De Caro and Macarthur 2008, 1). Likewise, renowned physicalist Daniel Stoljar: "[...] we live in an overwhelmingly physicalist or materialist intellectual culture" (Stoljar 2017, §17). In addition, there is at least some empirical evidence of the popularity of naturalism in a philpapers study. David Chalmers and David Bourget interviewed 931 philosophers "naturalism or non-naturalism?”; 25.8\% rejected naturalism, 24.3\% said "other" and 49.8\% agreed to naturalism (Chalmers and Bourget 2009). Ultimately, the dominance of naturalism can be seen in the large number of so-called naturalization projects that try to show that a certain phenomenon can be reduced to naturalistically respectable entities or eliminated entirely (De Caro 2011, 27). Popular goals of such naturalization projects are justification, knowledge, morality, normativity, intentionality or mathematical entities. Some of the most popular naturalization programs are gathered under the “Canberra Plan” label (Braddon-Mitchell and Nola 2008).

The dominance of naturalism itself has to be understood in the context of what Sellars called the "scientific image", akin to a scientific worldview or Weltanschauung. Some influential authors (cf. Section 2) have also at least implicitly acknowledged that naturalism amounts to a Weltanschauung, and not a mere thesis. One of the main problems here is, however, that those authors tend not to delve deeper into what it would mean for naturalism to be a worldview rather than an ordinary philosophical thesis. This paper aims to demonstrate how Jasper's and Dilthey's accounts of Weltanschauung can inform contemporary debates on naturalism and the scientific image. One of the main challenges of this undertaking is that there is only little engagement with either Dilthey or Jaspers in contemporary analytic philosophy. Wallraff already deplores in 1977 that "Jasper's influence in English speaking countries is virtually nil” (Wallraff 1977, 537f). That situation (which certainly applies to Dilthey, too) has probably been exacerbated over the last few decades, especially given the recent rise and resurgence of analytic metaphysics. There certainly are a number of excellent publications on the relevance of Dilthey and Jaspers which are anglophone, yet do not relate them to naturalistic thrusts in analytic philosophy. The ideas found in Nelson $(2018,2017)$ are among the most salient contributions to this topic, yet Nelson focusses on thinkers like Carnap and the positivists of the early 20th as proponents of 
naturalism, and tends to omit more recent iterations of naturalism. One further example is Beiser's (2014, 120f.) brief treatment of Dilthey's views on naturalism. However, he only discusses naturalism in the context of Dilthey's much more wellknown distinction between understanding versus explaining, and not as it pertains to his thought about worldviews. Seemingly, perhaps the only (recent) article that connects Jaspers' concept of a worldview with contemporary naturalism is Staiti (2017). It remains a genuine desideratum to apply Dilthey's and Jaspers' larger points to contemporary scientific naturalism at large.

After reconstructing an account of contemporary (scientific) naturalism (Section 2), this paper develops Dilthey's and Jaspers' respective accounts of worldviews generally speaking (Section 3). The last part (Section 4) suggests how some ideas of Dilthey and Jaspers, which are virtually simply not present in debates surrounding naturalism, can be utilized to potentially advance the dialectic.

\section{Naturalism in Analytic Philosophy - Thesis, Attitude, Project, or Worldview?}

Naturalism is usually just stated and debated in propositional form, i.e. as a truthevaluable claim or thesis. While there is no clear consensus on how naturalism is to be properly defined (Papineau 2015), the term "naturalism” usually denotes either ontological naturalism or methodological naturalism, or their conjunction. Ontological naturalism can be further explicated as the idea that all there is are the entities countenanced by the natural sciences. Ontological naturalism is usually given a more strict rendition as physicalism as the idea that only the entities countenanced by an idealized version of physics exist (e.g. Field 1992; Pettit 1993; Stoljar 2017). Methodological naturalism, on the other hand, states that philosophy ought to be aligned with the methodology of the natural sciences. The basic idea behind methodological naturalism is expressed in Quine's dictum that philosophy is continuous with the sciences (Quine 1960). How this claim is to be interpreted, is a great point of contention. Mario De Caro, for example, has compiled over a dozen different readings of this idea (De Caro 2011, cf. also Fischer and Collins 2015). For the purposes of this paper, a 'vague', not further interpreted understanding of methodological naturalism will suffice since the focus is on naturalism as a thesis as such versus the idea of naturalism as a worldview. 
Both ontological naturalism and methodological naturalism have been challenged in a way that pertains to their status as a thesis. Ontological naturalism is in need of defense against what has been called Hempel's dilemma. Methodological naturalism faces a dilemma regarding its coherence. As an attempt to vindicate them, ontological naturalism has been reconceived as an attitude (rather than a thesis) by Ney (2008), whereas methodological naturalism has been reconceived as a project in Rea (2002). In both cases, the reasoning is the same: if naturalism is not a thesis (but an attitude or project), then Hempel's dilemma and the coherence dilemma respectively are avoided. In what follows, I shall briefly develop these points. The reason is to demonstrate that at least some contemporary naturalists are cognizant of the problems that naturalism as a thesis faces. However, reconception as a project or attitude falls short of what will be attempted here in the next section, namely pointing out that naturalism might be better understood as a worldview.

Hempel's dilemma (Hempel 1969) states that ontological naturalism is either obviously false or trivial. Ontological naturalism is false if current physics is taken as a standard for a naturalistic ontology. This is because current physical science does not include and would be unable to account for non-physical properties including normativity and the mind. On the other hand, ontological naturalism is trivially true (and hence uninteresting) if the ontological naturalist merely promises that a future-ideal physics will account for everything, including normativity and the mind. ${ }^{1}$ It is trivial because the physical would obviously have to expand its domain in order to account for all phenomena even if it means including mental or normative ones. Neither horn of the dilemma is something an ontological naturalist could be content with. Hence, Hempel's dilemma has been reason for major concern among physicalists ever since it was first formulated.

The second problem, pertaining to methodological naturalism, is a threat to its coherence. To get this looming incoherence into view, it is helpful to look at a similar case of in the history of philosophy, namely (incidentally again) Hempel's empiricist criterion of meaning. The empirical criterion of meaning "qualifies a sentence as cognitively meaningful if its non-logical constituents refer [...] to observables" (Hempel 1950, 58). This leaves the idea that a sentence is meaningful if it is suitably connected to empirical observations. This would render metaphysical statements (of the kind positivists like Carnap and others loathed) meaningless because they would, by definition, not be related to empirical

1 This is a formulation of physicalism found, for example, in Loewer 2001 and Pettit 1993. 
observations in a way the empiricist countenances. The main problem is that the empiricist criterion, if true, is itself without meaning. This is trivially so because the empiricist criterion does not involve, or suitably relate to, empirical observations. Once the criterion is formulated, it would be without meaning, leading to an incoherence: if the empirical criterion of meaning does have meaning, it thereby does not have meaning. The empiricist criterion is thus incoherent because it cannot meet the very standard set by itself. ${ }^{2}$

Taking the incoherence of the empiricist criterion of meaning as a blueprint, something very similar besets methodological naturalism: the methodological thesis sets a standard for justification which it itself cannot meet. The methodological thesis states that philosophy should align itself with the natural sciences regarding its treatment of those philosophical problems which remain once all other problems have been deferred to the natural sciences. In this sense, whether or not a certain philosophical approach, statement, or theory is justified hinges upon whether or not it is properly aligned with some kind of natural-scientific methodology in the sense that philosophical statement or theorem can at least be countenanced from a natural-scientific standpoint.

Some naturalists, Ney (2008) and Rea (2002), have developed a defence against Hempel's dilemma and the coherence problem that requires naturalism to be reformulated as a stance, attitude, or "oath".

Apart from this debate whether naturalism can be reconceived in this manner as a stance, attitude or project, there has been an almost implicit acknowledgment by some influential authors that naturalism is a Weltanschauung (or some of its linguistic cognates). Most notably, Wilfrid Sellars's developed his own grand holistic naturalistic vision with the idea of a scientific image potentially replacing the manifest image in the future (Sellars 1962). Gillett and Loewer state that every "era has its Weltanschauung and in much contemporary philosophy the doctrine of 'physicalism' plays this role" (Gillett and Loewer 2001, ix). Similarly, Stoljar admits that "physicalism is in many ways the Weltanschauung of modern analytic philosophy" (Stoljar 2010, 2). Kim states that if "contemporary analytic philosophy can be said to have a philosophical ideology, it is, unquestionably, naturalism" (Kim 2003, 84).

2 Of course, Hempel was aware of this issue, being the exceptional thinker that he was. This is apparent in the rhetorical question he himself formulates: "What kind of sentence, it has often been asked, is the empiricist meaning criterion itself? [...] when judged by its own standard, is it not devoid of cognitive meaning?" (Hempel 1950, 59). Hempel does not directly meet this argument, but rather seems to concede its force, at least in that same paper. This incoherence challenge for the empiricist criterion of meaning has contributed to the eventual demise of logical positivism. 
These usages of "image”, "Weltanschauung”, and "ideology" clearly betray the fact that these thinkers acknowledge that naturalism is more than just a philosophical doctrine like any other. For example, externalism about epistemic justification, while having perhaps wide-ranging implications, does not qualify as a Weltanschauung like naturalism. Unfortunately, these authors tend not to further specify what they mean by "Weltanschauung" or its cognates. Seemingly, the only authors in that tradition who has thought deeply about what a scientific image of the world, as naturalism presents it, entails, is Wilfrid Sellars.

In Philosophy and the Scientific Image of Man, Sellars famously distinguishes the manifest image from the scientific image, both of which are idealizations of two different conceptual frameworks. The manifest image is the image of "manin-the-world", the "framework in terms of which man encountered himself" (Sellars 1962, 6f.), so on a somewhat simplified reading, the ordinary worldview as a conceptual framework which itself is not totally alien to science, but rather already incorporates parts of scientific reasoning and vocabulary. For example, talk about "bacteria" is already part of the manifest image even if they are not discernible by the naked eye. In contrast, the scientific image is the conceptual framework in virtue of theoretical postulation insofar natural sciences posit certain fundamental entities which, in its ideal form, offers a complete account of the world, what there really is. While the manifest image is deemed at least useful, the scientific image and the manifest image are in a rivalry. Sellars famously hopes for a synoptic view in which the authoritative scientific image is supplemented with a "language of community and individual intentions" (Sellars 1962, 40). Sellars' rendition of what the "scientific image" has become perhaps the most influential version of naturalism as a worldview, at least in the world of Anglophone philosophy. His ideas are enlightening and their implications hotly debated to this day, especially the question what a synoptic view of the two images would entail in detail. ${ }^{3}$

Unfortunately, Sellars himself does not seem to reflect much on the nature of the scientific image as an image. It is clear that Sellars is on the right rack in using the term "image" to denote our view of the world as it is fashioned by the sciences, implicitly acknowledging that having an "image" of the world is something other than merely holding a certain belief or endorsing a set of propositions. These aspects are arguably part of the scientific image too, but there seems to be a surplus Sellars (and other analytic philosophers) using such terms aim to convey, yet not make explicit. The following section aims at teasing out that surplus conveyed by terms like "image”, "ideology", and "Weltanschauung” with the help of Dilthey and Jaspers.

3 This is a different debate however, cf. the issue edited by Gabbani (2012). 


\section{Dilthey and Jaspers on Weltanschauung}

One of the most vexing aspects about naturalism as a topic of research is that at least some aspects of it are treated in an a-historical manner. Relatively long before naturalism became the near-orthodoxy in analytic philosophy, it had been a topic of interest in the unhelpfully so-called "Continental" tradition. For Examüle, Wilhelm Dilthey and Karl Jaspers had both been interested in the issue of Weltanschauungen and worldimages. ${ }^{4}$ Within their respective engagements with the nature of Weltanschauungen, naturalism - especially ontological naturalism ("materialism" in older diction) - figured as just one salient type of Weltanschauung. This section is dedicated to assembling some crucial aspects of their respective treatments of Weltanschauung without providing a full reconstruction of their accounts lest this paper loses focus.

Dilthey was arguably the first thinker to make Weltanschauungen and Weltbilder (worldviews and worldimages) the main topic of a length-long monograph. He suggests that worldviews have always been part of Western civilization ever since the inception of Western philosophy with the Pre-Socratics. To understand what worldviews are on Dilthey's account, we have to understand the trifecta of concepts: life, metaphysics, and worldview.

The concept of life is arguably the main focal point of Dilthey's whole system. One of the key aims motivating Dilthey to introduce his conception of life is to overcome the Cartesian subject-object dualism. Life is all-encompassing in the sense that everything there is, part of life in some way or another. Mental life is, accordingly, only one aspect of life (GS I, 15). Dilthey's conception of life has similarities to the way in which the term "consciousness" is sometimes used in philosophical parlance, yet aims to disavow its subjectivist connotations.

More importantly in the current context, life is a riddle, or rather life poses a riddle (Rätsel): "The center of all incomprehensibility are procreation, birth, development and death" (Dilthey, GS VIII, 81). ${ }^{5}$ The inescapable, mortal questions of life pose a seemingly intractable enigma. Dilthey posits that worldviews are a reaction to life's enigma as an attempt to provide a totalizing view of life that makes sense of the enigmas or explains it away. Worldviews offer a systematisation and structuring of the whole of human experience into a set of problems and solutions. ${ }^{6}$

4 In what follows, the English translations of Dilthey and Jaspers are provided by myself.

5 "Der Mittelpunkt aller Unverständlichkeiten sind Zeugung, Geburt, Entwicklung und Tod".

6 "Das ist die Struktur der Weltanschauung. Was im Lebensrätsel verworren, als ein Bündel von Aufgaben enthalten ist, wird hier in einen bewußten und notwendigen Zusammenhang von Problemen und Lösungen erhoben; dieser Fortgang erfolgt in gesetzmäßig von innen bestimmten Stufen: daraus folgt, daß jede Weltanschauung eine Entwicklung hat und in dieser zur Explikation 
Through the lens of a worldview, the riddle of life becomes tangible and seemingly solvable. Sciences cannot get such a unified picture, hence worldviews are something different from science. Worldviews give a descriptive (truth) and evaluative (goodness) picture of the world (Makkreel 2020, 39). Since worldviews are an expression of life that reflect on life itself, what worldview one subscribes to might be dependent on a person's psychic disposition, or more poetically, their lifeblood (Herzblut, Dilthey, GS VIII, 33). Yet, this also means that life is the "root" (Wurzel) of any worldview (Dilthey, GS VIII, 78).

\begin{abstract}
"World views are not products of thought. They do not arise from the mere will of knowledge. The conception of reality is an important factor in shaping it, but only one. They arise from life behavior, life experience, the structure of our psychic totality. The elevation of life to consciousness in the knowledge of reality, appreciation of life and the performance of the will is the slow and difficult work that mankind has done in the development of the outlook on life." (Dilthey, GS VIII, 86) ${ }^{7}$
\end{abstract}

Life - in Dilthey's sense - is the foundational, general.Worldviews are "products" of life which aim to provide a total representation, i.e. a picture, of the world. A worldview can then furthermore be given a concrete, more strict form as a metaphysical system. ${ }^{8}$ Worldviews (at least those Dilthey is interested in) are mutually incompatible and compete. ${ }^{9}$

Dilthey identifies three prime worldviews, iterations of which he traces through different stages of the history of philosophy: naturalism, idealism of

des in ihr Enthaltenen gelangt: so empfängt sie Dauer, Festigkeit und Macht, allmählich, im Verlauf der Zeit: sie ist ein Erzeugnis der Geschichte” (Dilthey, GS VIII, 84).

7 „Die Weltanschauungen sind nicht Erzeugnisse des Denkens. Sie entstehen nicht aus dem bloßen Willen des Erkennens. Die Auffassung der Wirklichkeit ist ein wichtiges Moment in ihrer Gestaltung, aber doch nur eines. Aus dem Lebensverhalten, der Lebenserfahrung, der Struktur unserer psychischen Totalität gehen sie hervor. Die Erhebung des Lebens zum Bewußtsein in Wirklichkeitserkenntnis, Lebenswürdigung und Willensleistung ist die langsame und schwere Arbeit, welche die Menschheit in der Entwicklung der Lebensanschauungen geleistet hat.“

8 Dilthey himself states that worldviews can be expressed as either religious, metaphysical, or scientific systems. The reason why I only stress metaphysics here is as follows. On the one hand, any religious system is at least in some sense metaphysical. Secondly, it is highly contentious whether scientific theories themselves are expressive of worldviews. The coming-to-be of modern science can certainly be viewed as a result of worldviews as such (as Heidegger 1997). Yet, a singular scientific theory like, say, Newton's mechanics is more difficult to be seen as expressive of a certain worldview. For example, one can reject a naturalistic or mechanistic image of the world and still endorse Newtonian mechanics as a true theory.

9 This reading of worldviews differs from Staiti $(2017,134)$ who posits that Dilthey posits worldviews as the Zeitgeist of an epoch. 
freedom, and objective idealism. Due to the current context, we shall only focus on naturalism.

Dilthey has a more holistic, total view of naturalism as a worldview, at least compared to the way "naturalism" is used in contemporary analytic philosophy. Since worldviews are supposed to provide a view onto the riddle of life, naturalism as a worldview is all-encompassing. ${ }^{10}$ According to Dilthey, naturalism as a worldview is a loose combination of empiricism (in epistemology, which Dilthey calls "sensualism"), materialism (in ontology), and a combination of hedonism and determinism (in ethics) (GA VIII, 101). Dilthey further defines it in the following manner:

"[The] process of nature is the only and the whole reality; apart from him there is nothing; Spiritual life is only formally differentiated as consciousness according to the properties contained in it from physical nature, and this content-wise empty determination of consciousness emerges from physical reality according to natural causality.” (GA VIII, 101) ${ }^{11}$

While his prose may seem somewhat strange to the contemporary reader, Dilthey simply states that according to naturalism everything is nature, not only in a stricter ontological sense, but also in the sense that every view we have onto the world, including mind itself and our understanding of the world, is to be viewed through this lens that it is natural as well as a variation of physical reality and natural causality. Accordingly, Dilthey views naturalism in stark opposition to any religious worldview and its "dreadful disciplining” ("furchtbare Disziplinierung"), from which naturalism gains its appeal (GA VIII, 101). Dilthey has wider understanding of naturalism, also containing the biological aspects of man, not merely physicalism, since man is bound to nature itself qua his biological and physical properties (GA VIII, 100). ${ }^{12}$

One of the most salient observations Dilthey makes is that worldviews have a peculiar status. They are prior to metaphysics, philosophy, and rational thought itself. To quote again, Dilthey states that world views are "not products of

10 Beiser $(2014,49)$ argues that Dilthey's focus on the riddle of life betrays an influence by Schopenhauer's work on his metaphilosophical views expressed in his Weltanschuungslehre.

11 "[Der] Prozeß der Natur ist die einzige und die ganze Wirklichkeit; außer ihm besteht nichts; das geistige Leben ist nur formal als Bewußtsein nach den in diesem enthaltenen Eigenschaften von der physischen Natur unterschieden, und diese inhaltlich leere Bestimmtheit des Bewußtseins geht aus der physischen Wirklichkeit nach Naturkausalität hervor.”

12 Dilthey further characterizes naturalism by briefly explicating two of its problems: a circularity of justification and the fact that its practical component is too simplistic to account for the development of societal life (Dilthey, GA VIII, 101f.; also 105). He furthermore analyses it as implying a form of mechanistic understanding of the mind which seems eerily reflective of even a great deal of contemporary philosophy of mind (Dilthey, GA VIII, 104f). 
thought" (Dilthey, GS VIII, 86). It is rather the other way around: worldviews motivate the construction of systems of thought in an attempt to capture the content of a worldview. For example, naturalism as a "reaction" to religion is a certain view onto life (Lebensverfassung) that has become philosophy. This means that, according to Dilthey, worldviews themselves can be given expression as a metaphysical system, but worldviews themselves are still prior to metaphysical systems. $^{13}$

Despite having worked on virtually the same topic, Jaspers' Psychologie der Weltanschauungen only refers to Dilthey a few times (Jaspers 1925, 11, 98, 132, 142, 160) and offers no substantial debate of Dilthey's Weltanschuungslehre. ${ }^{14}$ Interestingly enough, Moritz Schlick (of all people) calls Jasper's Weltanschauungslehre a work of "verstehende Psychologie", thereby himself drawing a comparison to Dilthey (Schlick 2012, 516). In what follows, I will very briefly reconstruct Jaspers' notion of Weltanschauungen in a way that presents it as congenial to Dilthey's account without dwelling too long on their, otherwise very important, differences.

Jaspers' treatment of worldviews is, as the title of his work suggests, psychological. His goal is to compile and reconstruct an overview of different psychological worldviews. His project is accordingly operating with a fundamental presupposition of psychology and large swathes of traditional philosophy, namely the subject-object-distinction (Jaspers 1925, 38). Jasper's account of worldview is more "subjectivist” than Dilthey's. Whereas the aim behind Dilthey's philosophy of life is overcoming the subject-object-distinction, Jaspers can be said to reify this distinction by understanding worldviews as a mere psychological attitudes or stances (Einstellungen) of looking at the world (Jaspers 1925, 18f). ${ }^{15}$ According to Dilthey, the fundamental setting of psychology is a subject cognizing an object; $a$ fortiori then the psychology of world views deals with subjects cognizing objects (Jaspers 1925, 21). This tends to carry the implication that we could attain a view

13 The idea that metaphysical positions themselves are worldviews is mirrored in Rudolf Carnap's more well-known positivist critique of Heidegger. There is an irony here: Both Heidegger was certainly influenced by Dilthey's account of worldviews as was Carnap. Just Carnap used Dilthey's positive account of metaphysics as worldviews to critique Heidegger's development of metaphysics.

14 This is perhaps not surprising given that the influences Jaspers himself quotes are Hegel, Kant, Kierkegaard, Nietzsche and Max Weber (Jaspers 1925, 11-13).

15 "Even during their early friendship Heidegger was very critical of Jaspers's philosophy; he wrote a commentary on Psychology of World Views, in which he claimed that Jaspers's methodological approach remained ensnared in the falsehoods of subjectivist metaphysics and Cartesian ontology, and that it illegitimately introduced the categories of Weberian sociology into philosophical analysis.“ (Thornhill and Miron 2020, 8). 
onto the world which is free from such a psychological "distortion", which is an idea that Dilthey would have rejected.

Worldviews are something universal, a kind of belief system about the whole cosmos that manifests itself in practical human conduct (Jaspers 1925, 1). Worldviews are not merely "intellectual mechanism[s]", but are entangled with or baked into (verwebt) one's whole life, of which the classical example are the Ionian metaphysicians (Jaspers 1925, 35, cf. also 126). ${ }^{16}$ According to Jaspers's theory of worldimages (Weltbilder), worldimages fixate a part of whole reality and take that part to be the whole (Jaspers 1925, 123f, cf. also 129).

His notion of worldview (Weltanschauung) is further bifurcated into attitudes (Einstellungen) as the subjective part of a worldview and worldimages (Weltbild) as the objective part. It appears that what Jaspers idea of worldimages (Weltbilder) is coeval to Dilthey's notion of worldviews (Weltanschauungen) (Jaspers 1925, 38). In the current context, only Jaspers' worldimages are pertinent. He characterizes them as something that is not psychological, but rather conditions and results of “psychological existence” (Jaspers 1925, 122). As such, they serve as a kind of existential enclosure or hull (Gehäuse) which we cannot easily get out of (Jaspers 1925, 123). A worldimage denotes what one always already finds plausible and unquestionable, of which nothing sensible or reasonable can be external to. Yet, worldimages themselves are always subject-transcendent in the sense that different subjects may only be aware of parts or components of the kinds of worldimages that Jaspers describes and accounts for.

There are three different concrete worldimages that Jaspers gives us: the sensual-spatial worldimage, the psychic-cultural worldimage, and the metaphysical worldimage. Jaspers further segments the sensual-spatial worldimage into the natural-mechanical, natural-historical, and natural-mythical worldimage. Yet, he admits that these three subdivisions of the sensual-spatial worldimage may be jointly instantiated in certain people (Jaspers 1925,141$).{ }^{17}$ Given that our current context is naturalism, we shall only focus on the natural-mechanical, because it is akin to Dilthey's treatment of naturalism as well as the current scientific naturalism in analytic philosophy.

The natural-mechanical worldimage is materialism in different versions stretching from Democritus to the positivism of Jaspers' own time. According to him, the natural-mechanical worldimage takes what can be sensorily experienced

16 Interestingly, Dilthey takes this Verwebung to be one of the defining differences between worldviews and ideologies: ideologies can simply, as it were, be cast aside through sufficient intellectual manipulation or development.

17 According to Jaspers, the natural-historical worldimage is more akin to what we would call today "biologism", which itself might be considered a species of current naturalism. 
and that which has spatio-temporal properties as the only things that are real. This, of course, coincides with that which can be in principle a proper object of naturalscientific inquiry, e.g. biology, chemistry, geology, or physics:

"The natural-mechanical worldview is never seen directly, but found indirectly through analysis and abstraction, through experiment and mathematical calculation. Theoretically, the phenomena are thought to be based on something, something that remains as matter, energy, atom, electron, etc., as something as purely quantitative as possible. The world is only measurable movement and potential movement. The vehicle of research is mathematics; and only insofar as mathematics is applicable can a mechanical world view arise. Everything qualitative, actually descriptive, everything that appears essential in itself is pushed out of the world. Nature is de-qualified and thus de-souled. It is formulated in exact lawlike terms, thus made calculable and thus controllable. This worldview only states: We only recognize everything as far as we can make it. Nature becomes a tool of the spirit - as a mechanism, an apparatus, it thus becomes very abstract in terms of content, very general. In this worldview one does not see what is usually called reality and has abundance, but a specific unreality with which, since one side of everything real, the greatest effects can be achieved in it. This view of the world encompasses that which in nature is completely subject to us through calculation, that is, above all, the world according to its spatial and temporal side.” (Jaspers $1925,137 f.)^{18}$

Focussing on mathematization, matter, energy, measurability, and movement, Jaspers in essence describes here the worldview of scientific naturalism in its most abstract, least concrete form. He adds:

"But once this worldview has taken hold of people's minds, it is carried over to everything. It becomes satisfactory even where it loses its essential characteristics: the theoretical calculation of effects that can be experimentally controlled. [...] So the psychiatrist enjoys "brain mythology", the psychologist enjoys mass theories of the unconscious. Measuring, counting, and experimenting are so important that everything becomes an end in itself as a mere

18 „Das naturmechanische Weltbild wird nie direkt anschaulich gesehen, sondern indirekt durch Analyse und Abstraktion, durch Experiment und mathematische Rechnung gefunden. Es wird den Erscheinungen theoretisch etwas zugrunde liegend gedacht, etwas, das als Materie, Energie, Atom, Elektron usw., als etwas möglichst bloß Quantitatives übrigbleibt. Die Welt ist nur meßbare Bewegung und potentielle Bewegung. Das Vehikel der Forschung ist Mathematik; und bloß soweit Mathematik anwendbar ist, kann ein mechanisches Weltbild entstehen. Alles Qualitative, eigentlich Anschauliche, alles, was an sich wesenhaft erscheint, wird aus der Welt verdrängt. Die Natur wird entqualifiziert und damit entseelt. Sie wird in exakte Gesetzesbegriffe gefaßt, damit berechenbar und dadurch beherrschbar. In diesem Weltbild allein heißt es: Wir erkennen alles nur so weit, als wir es machen können. Die Natur wird ein Werkzeug des Geistes als Mechanismus ein Apparat, sie wird damit inhaltlich ganz abstrakt, ganz allgemein. In diesem Weltbild sieht man nicht das, was gewöhnlich Wirklichkeit heißt und Fülle hat, sondern eine spezifische Unwirklichkeit, mit der, da die eine Seite alles Wirklichen ist, sich die allergrößten Wirkungen in dieser erzielen lassen. Dies Weltbild umfaßt eben das, was an der Natur uns durch Berechnung ganz unterworfen ist, also vor allem die Welt nach ihrer räumlichen und zeitlichen Seite.“ 
operation, and one no longer knows why it is all being done. One consoles oneself with the fact that everything will be fruitful at some point." (Jaspers 1925, 138) ${ }^{19}$

Jaspers anticipates here what John Dupré has more recently called scientific imperialism, i.e. the notion of methods and contents of the natural sciences encroaching onto areas they ought to have nothing to do with (Dupré 1994). Jaspers' own timely example here is "brain mythology" which can be taken to be the equivalent of our "neurohype" in his own era. This is not to say that Jaspers was in any meaningful way "anti-science". Jaspers, himself a scientist, obviously has great reverence for the achievements of modern science, but only insofar as science stays within the bounds of science, and does not aim to elevate itself to the status of a worldview. ${ }^{20}$

One of the main issues in which Jaspers falls behind Dilthey is that he at least sometimes seems to imply worldviews are more or less merely contingent psychological phenomena. Dilthey's analysis is more profound in that he tries to unearth that there being worldviews is a necessary property of there being a world inhabited by rational beings. A mere typology of worldviews as an analytic compilation fails, it seems to me, to account for the transcendental status of worldviews that Dilthey posits. Accordingly, Jaspers' project is prone to criticize worldviews in terms of their degree of rationality such that on his view, worldviews "habitually stand in the way of genuine knowledge" (Thornhill and Miron 2020, 15). On Dilthey's view, in contrast, worldviews are not merely akin to a pair of glasses that distorts our view onto the world, as it were. This is also reflected in Jaspers' positing that worldviews are themselves psychological entities and not metaphysical ones as Dilthey argues. Jaspers usage of the word "metaphysical" (metaphysisch) seems to mean speculative metaphysics, and he is at least not very explicit about the fact that what his mechanical worldview (akin to contemporary naturalism) is itself a metaphysical position.

Despite this important difference, Jaspers and Dilthey seem to agree on a number of very crucial points regarding the concept of worldviews. For the current context, I shall focus on two salient aspects we can extract from their respective accounts.

19 „Wenn aber dieses Weltbild sich einmal der Köpfe bemächtigt hat, so überträgt es sich auf alles. Es wird befriedigend selbst da, wo es seine wesentlichen Merkmale: theoretische Berechnung von experimentell zu kontrollierenden Effekten, verliert [...] So erfreut sich der Psychiater an "Hirnmythologie", der Psychologe an massenhaften Theorien von Außerbewußtem. Man legt auf Messen, Zählen, Experimentieren solchen Wert, daß alles dieses als bloßer Betrieb Selbstzweck wird, und man nicht mehr weiß, wozu denn das alles geschehe. Man tröstet sich damit, das werde alles schon irgendwann fruchtbar sein.“

20 This is how I interpret Alan Olson's remark that "success of science rests squarely on its selfdisciplined ability to suspend or bracket questions pertaining to an all-encompassing world-view [...].” (Olson 1979, 13). 
First, metaphysics is in a tight-knit relation with the concept of worldviews. Dilthey and Jaspers agree that worldviews are logically prior to metaphysics such that metaphysics are "downstream" of the concept of worldviews. That is, the worldview one has always already informs the metaphysical system one finds most plausible. Furthermore, metaphysical systems are not to be had without worldviews to the effect that metaphysical systems are an attempt to give a given worldview a more systematic and propositional (i.e. truth-evaluable) expression. Secondly, worldviews have practical significance. ${ }^{21}$ That is, a worldview is not something one simply adopts for this or that reason. As Jaspers notes too, worldviews are not a product of thought. Rather, it is the case that what we take to be prima facie in need of justification is pre-conditioned or pre-formed by one's worldview. Our worldviews are thus interwoven with our selves in a manner that makes it difficult to look at them from the "outside" in the same manner that one can entertain a philosophical thesis of lesser scale. With these two points at hand, the next section tries to tease out some according suggestions for the current discourse on naturalism in analytic philosophy.

\section{What can Analytic Philosophy Gain from Dilthey and Jaspers?}

Thinkers like Sellars, Kim, Stoljar, or Loewer are correct in calling naturalism an image, worldview, or Weltanschauung. However, they do not seem to have made the effort to draw out some of the more conspicuous implications of what this means. This last section is dedicated to pinpoint some ways in which the contemporary debate about naturalism in analytic philosophy can benefit from the ideas of Dilthey and Jaspers. ${ }^{22}$

First, if naturalism is a worldview, it is neither simply a thesis nor simply an attitude or project. It is rather than the case that naturalism as a worldview is the motivating foundation for naturalisms which take shape as a thesis, attitude, or project. Phrased differently, accounts of naturalism which view it as a thesis, project, or attitude fail to see how these are mere specific guises or forms of

21 I have written about some of the practical and social imports of the scientific image in Spiegel (2020).

22 Buhler $(1980,78)$ states that Dilthey is "steeped in the Western naturalist tradition" which seems to be simply an unfortunate misreading which is not only challenged by his critical approach to the scientific worldview, but also by his preference for understanding psychology over explanatory psychology as a method which is not amenable to natural-scientific research (cf. also Nelson 2017, 90). 
expression of naturalism as a worldview. This supports the following counterfactual: had naturalism as a worldview not achieved the dominance it has had for a long time, then naturalism as a thesis (and its reconception as an attitude or project) would not have the unquestioned appeal they have.

Moreover, we can learn from Dilthey and Jaspers that metaphysics and the concept of worldview generally share a close conceptual relation. According to them, all metaphysics is in a sense a worldview or is at least expressive of an underlying worldview. Accordingly, the kind of naturalism motivating a multitude of different naturalization projects in philosophy is itself expressive of a worldview. Hence, metaphysics is not to be looked at as a bout of reason alone, but as an intellectual conflict that is ultimately ideological in nature. For if Dilthey is correct that metaphysics is rooted in life (in his more technical sense), then metaphysical disputes proper are something in which everything is ultimately on the line.

For the debate regarding contemporary naturalism this means that naturalism itself has a different epistemological status, and it is not an ordinary philosophical thesis like any other. Worldviews are presuppositional to other kinds of more surface beliefs in virtue of being a result of life as a whole (Dilthey 1960, 1965). Those brought up into the scientific image are "entangled" 23 with a naturalistic worldview to the effect that we are disposed to always already find it plausible and are biased in its favour. Worldviews therefore have a 'headstart' over the rational control we can exert over beliefs. This notion is present in Jaspers insofar he states that limit situation (Grenzsituationen), like suffering, struggle, fate, death, shape worldviews (Jaspers 1925, 202). Such limit situations are not anything like rational discourse, but rather experiences that affect us in a way argument simply cannot.

This puts us, as philosophers, into a difficult position. Academic philosophy is predicated on the conviction that we can influence each other and change each others' minds through discourse, through rational discourse, through the game of giving and asking for reasons. Yet, if naturalism is in fact a worldview rather than a mere thesis this conviction is inappropriate. Or put differently: attempts at arguing against naturalism face challenges which are not present in other debates. For example, Gettier's famous arguments against the justified true belief-theory of knowledge influenced the whole epistemological discourse by merely attacking the content of that doctrine. It is, however, arguably not sufficient for an analogous dialectical movement in the naturalism debate. This is because in this debate the

23 „Was wir Weltbild nennen, ist uns nicht bloß ein fremdes Gegen. über, das uns nicht berührt, sondern es ist mit uns mehr oder weniger verwachsen. Was wir die Seele, das Ich, die Persönlichkeit nennen, ist immer ein Ganzes, in dem Weltbilder so assimiliert sind, daß mit ihrem Wegfall auch die Seele aufhören würde.“(Jaspers 1925, 126). 
content of naturalism, qua worldview, is not as fixed as that of an ordinary philosophical idea.

This can, in principle, be demonstrated for both ontological and methodological thesis. For example, any criticism of physicalism has led to reformulations of physicalism rather than an admission that physicalism itself might be flawed (cf. Stoljar 2017 who traces this development). On the one hand, critique of reduction-based physicalism has led to the proposal of supervenience-based physicalism. On the other hand, Hempel's dilemma lead thinkers like Ney (cf. Section 2) not to reject physicalism, but to view it as an attitude. Why are arguments against physicalism not enough to change the minds of physicalists, but merely motivate them to come up with a different version? The best explanation I can muster is that naturalism as a worldview is more fundamental, and operative in the background. Some form of naturalism must be correct, as it were, so arguments against naturalism simply lead to more contorted rehashes of an intuitive idea that, as a worldview, has no definitive form, but can actualize itself under different guises.

The moral then would be - for both proponents and opponents of naturalism to stop treating naturalism as a thesis and start treating it as a worldview that cannot be argued for or against in the same way as ordinary philosophical theses. As a worldview, naturalism is more akin to certain fundamental religious, moral, ideological, or existentialist convictions. A statement with an analogous justificatory status to "naturalism is true" would be "humans are intrinsically morally good". It is improbable that someone who believes from the bottom of their heart that humans are intrinsically morally good, will be persuaded by good arguments or empirical evidence used to support the negation of that statement. What forms, determines, and potentially changes the adherence to a worldview is less tangible and less controllable than rational discourse. It is part of the realm of earliest childhood experience, education, and perhaps what recently has been called transformative experience (Paul 2014). If limit situations shape worldviews, it is perhaps plausible to assume that adherence to naturalism can only be changed through such extraordinary experiences. Naturalism as a worldview should therefore be treated accordingly in philosophical discourse, or should perhaps be omitted from philosophical discourse altogether.

\section{References}

Beiser, F. 2014. After Hegel. Princeton: Princeton University Press.

Braddon-Mitchell, D., and R. Nola, eds. 2008. Conceptual Analysis and Philosophical Naturalism. Cambridge: MIT Press. 
Buhler, I. 1980. Wilhelm Dilthey. A Hermeneutic Approach to the Study of History and Culture. The Hague/Boston//London: Martinus Nijhoff Publishers.

Chalmers, D., and D. Bourget. 2009. "The PhilPapers Surveys. Preliminary Survey results.” http://philpapers.org/surveys/results.pl (accessed January 15, 2019).

De Caro, M. 2011. "Beyond Scientism." In New Perspectives on Pragmatism and Analytic Philosophy, edited by C. Rosa, 21-34. Amsterdam/New York: Brill/Rodopi. https://doi.org/ 10.1163/9789042033221_003.

De Caro, M., and D. Macarthur. 2008. “Introduction.” In Naturalism in Question, edited by M. De Caro, and D. Macarthur, 1-17. Cambridge: Harvard University Press.

Dilthey, W. 1965. Der Aufbau der geschichtlichen Welt in den Geisteswissenschaften, Gesammelte Schriften, Vol. VII. Stuttgart: Teubner.

Dilthey, W. 1960. Weltanschauungslehre, Gesammelte Schriften, Vol. VIII. Stuttgart: Vandenhoeck and Ruprecht.

Dupré, J. 1994. “Against Scientific Imperialism.” PSA: Proceedings of the Biennial Meeting of the Philosophy of Science Association 2: 374-81.

Field, H. 1992. "Physicalism." In Inference, Explanation, and Other Frustrations, edited by J. Earman, 271-91. Berkeley: University of California Press. https://doi.org/10.1525/ 9780520309876-013.

Fischer, E., and J. Collins. 2015. Experimental Philosophy, Rationalism and Naturalism. Rethinking Philosophical Method. London: Routledge.

Gabbani, C., ed. 2012. "Between Two Images? An Introduction." Humana Mente 5 (21): V-XXIX.

Heidegger, M. 1997. “The Age of the World Picture.” In Science and the Quest for Reality, 70-88. Basingstoke: Palgrave Macmillan.

Hempel, C. 1950. "Problems and Changes in the Empirical Criterion of Meaning." Revue Internationale de Philosophie 4 (11): 41-63.

Hempel, C. 1969. "Reduction: Ontological and Linguistic Facets." In Philosophy, Science, and Method: Essays in Honor of Ernest Nagel, edited by S. Morgenbesser, P. Suppes, and M. White, 179-99. St. Martin's Press.

Jaspers, K. 1925. Psychologie der Weltanschauungen. Berlin: Springer.

Kim, J. 2003. "The American Origins of Philosophical Naturalism." Journal of Philosophical Research 28: 83-98.

Loewer, B. 2001. "From Physics to Physicalism." In Physicalism and its Discontents, edited by C. Gillett, and B. Loewer. Cambridge: Cambridge University Press.

Nelson, E. 2018. "Dilthey and Carnap: The Feeling of Life, the Scientific Worldview, and the Elimination of Metaphysics." In The Worlds of Positivism, edited by J. Feichtinger, F. Fillafer, and J. Surman, 321-46. New York: Springer. https://doi.org/10.1007/978-3-319-65762-2_ 12.

Nelson, E. 2017. “Overcoming Naturalism from within: Dilthey, Nature, and the Human Sciences." In Hermeneutic Philosophies of Social Science, edited by B. Babich, 89-108. New York/ Berlin: De Gruyter.

Ney, A. 2008. “Physicalism as an Attitude.” Philosophical Studies 138 (1): 1-15.

Olson, A. 1979. Transcendence and Hermeneutics. An Interpretation of the Philosophy of Karl Jaspers. The Hague/Boston//London: Martinus Nijhoff Publishers.

Papineau, D. 2015. “Naturalism." In The Stanford Encyclopedia of Philosophy, edited by E. Zalta. Stanford Encyclopedia of Philosophy. https://plato.stanford.edu/entries/naturalism/ (accessed February 23, 2021).

Paul, L. 2014. Transformative Experience. Oxford: Oxford University Press. 
Pettit, P. 1993. “A Definition of Physicalism.” Analysis 53 (4): 213-23.

Quine, W. V. 0. 1960. Word and Object. Cambridge, MA: MIT Press.

Rea, M. 2002. World without Design: The Ontological Consequences of Naturalism. Oxford: Clarendon Press.

Rorty, R. 2010. "Naturalism and Quietism." In Naturalism and Normativity, edited by M. De Caro, and D. Macarthur, 55-68. Columbia University Press.

Schlick, M. 2012. “[Rezension von:] Karl Jaspers, Psychologie der Weltanschauungen.” In Gesamtausgabe, Abteilung I, Vol. 5, edited by Stadler, and Wendel, 515-7. New York: Springer.

Sellars, W. 1962. "Philosophy and the Scientific Image of Man.” In Wilfrid Sellars, Science, Perception, Reality, 1-40. Atascadero: Ridgeview Publishing.

Spiegel, T. J. 2020. “Ist der Naturalismus eine Ideologie?” Deutsche Zeitschrift für Philosophie 68 (1): 51-71.

Staiti, A. 2017. “Naturalism as Weltanschauung." Discipline filosofiche 27 (1): 131-46.

Stoljar, D. 2010. Physicalism. London \& New York: Routledge.

Stoljar, D. 2017. "Physicalism." In The Stanford Encyclopedia of Philosophy, edited by E. N. Zalta. Stanford Encyclopedia of Philosophy. https://plato.stanford.edu/archives/win2017/ entries/physicalism/ (accessed August 27, 2018).

Thornhill, C., and R. Miron. 2020. "Karl Jaspers." In The Stanford Encyclopedia of Philosophy. edited by E. N. Zalta. Stanford Encyclopedia of Philosophy. https://plato.stanford.edu/ archives/spr2020/entries/jaspers/ (accessed March 25, 2021).

Wallraff, C. F. 1977. "Jaspers in English: A Failure of Communication.” Philosophy and Phenomenological Research 37 (4): 537-48. 